\title{
PREDIKSI HARGA SAHAM DENGAN MENGGUNAKAN METODE MOVING AVERAGE
}

\author{
Baiq Nurul Suryawati ${ }^{1}$, Laila Wardani ${ }^{2}$, Sulaeman Sarmo ${ }^{3}$ \\ Iwan Kusmayadi ${ }^{4}$, Muttaqillah ${ }^{5}$
${ }^{1}$ Magister Manajemen Fakultas Ekonomi dan Bisnis, Universitas Mataram E-mail: nurul.suryawati@unram.ac.id
2,3,4,5Fakultas Ekonomi dan Bisnis, Universitas Mataram

\section{ARTICLE INFO}

Keywords :

predictions, stock prices, chartnexus ${ }^{\circledR}$

Kata Kunci :

prediksi, harga saham, chartnexus®

\section{How to cite :}

Suryawati, Baiq Nurul., Wardani, Laila., Sarmo, Sulaeman, Kusmayadi, Iwan., Muttaqillah., (2019). Prediksi Harga Saham Dengan Menggunakan Metode Moving Average, 9(2), 107-121

DOI :

http://dx.doi.org/10.29303/jmm.v9i2.508

Dikumpulkan : 28 November 2019

Direvisi : 22 Januari 2020

Dipublikasi : :20 Mei 2020

ABSTRACT

This research introduces the use of the Chartnexus ${ }^{\circledR}$ application in order to understand how to implement the calculation of stock price predictions in a variety of methods, one of which is the moving average method. The results showed that the patterns shown by various indices in Indonesia match those described in the Eliot Wave Principle. In the significance test, there is a difference between the prediction of moving averages both in groups of 20,50,100 and 200 on various indices on the Indonesia Stock Exchange. Based on the test of mean rank, it is shown that sectoral indices have better averages, therefore, it is recommended to construe a portfolio in certain stocks within particular industries such as AGRI, CONSUMER, MINING, MISC-IND, and MANUFACTURE. In addition, a comprehensive understanding of investors about the business is needed before investors make investments.

Penelitian ini memperkenalkan penggunaan aplikasi chartnexus ${ }^{\circledR}$ untuk memahami bagaimana secara implementatif prediksi harga saham dilakukan dengan berbagai metode, salah satunya adalah metode moving average. Hasil penelitian menunjukkan bahwa pola yang ditunjukkan oleh berbagai indeks di Indonesia sesuai dengan yang digambarkan dalam Eliot Wave Principle. Pada uji signifikansi, terdapat perbedaan antara prediksi moving average baik pada kelompok 20, 50,100, dan 200 pada berbagai indeks di Bursa Efek Indonesia. Berdasarkan uji pemeringkatan mean ditunjukkan bahwa indeks sektoral memiliki rata-rata yang lebih baik, oleh karena itu, disarankan untuk membentuk portofolio pada saham-saham dalam industri sektor tertentu seperti AGRI, CONSUMER, MINING, MISC-IND, dan
\end{abstract}




\begin{tabular}{|l|l|}
\hline & $\begin{array}{l}\text { MANUFACTURE. Selain itu pemahaman investor akan } \\
\text { bisnis secara komprehensif tentu saja tetap diperlukan } \\
\text { sebelum investor melakukan investasi. }\end{array}$ \\
\hline $\begin{array}{l}\text { Copyright } \\
\text { reserved. }\end{array}$ & $\mathbf{2 0 2 0}$ JMM UNRAM. All rights \\
\hline
\end{tabular}

\section{PENDAHULUAN}

Saham perusahaan go public sebagai salah satu komoditi investasi tergolong berisiko tinggi, karena sifatnya yang peka terhadap perubahan-perubahan yang terjadi baik oleh pengaruh yang bersumber dari luar ataupun dari dalam negeri seperti perubahan dibidang politik, ekonomi, moneter, undang-undang atau peraturan maupun perubahan yang terjadi dalam industri dan perusahaan yang mengeluarkan saham itu sendiri. Untuk mengantisipasi perubahan harga saham tersebut maka diperlukan analisis saham. Terdapat dua pendekatan yang sering dilakukan untuk menganalisis harga saham, yaitu analisis fundamental dan analisis teknikal.

Analisis fundamental pada dasarnya adalah melakukan analisis historis atas kekuatan keuangan, dimana proses ini sering juga disebut sebagai analisis perusahaan (company analysis), sementara itu analisis teknikal merupakan studi yang dilakukan untuk mempelajari berbagai kekuatan yang berpengaruh dipasar saham dan implikasi pada harga saham. Husnan (2001) mengulas Moving Average sebagai salah satu metode dalam analisis teknikal, moving average dihitung berdasarkan atas jumlah hari tertentu. Selanjutnya, Gumilang (2012) menjelaskan bahwa moving average merupakan harga rata-rata pada periode tertentu. Penelitian Kusumawardana (2016) menunjukkan hasil bahwa analisis teknikal cocok dan tepat untuk meramalkan harga saham guna menentukan buy, sell, and hold, untuk mengoptimalkan return saham serta menunjukkan bahwa strategi aktif mampu mengungguli strategi pasif ketika pasar fluktuatif. 
Tabel 1. Perkembangan Indeks di Indonesia dan Beberapa Negara di Dunia.

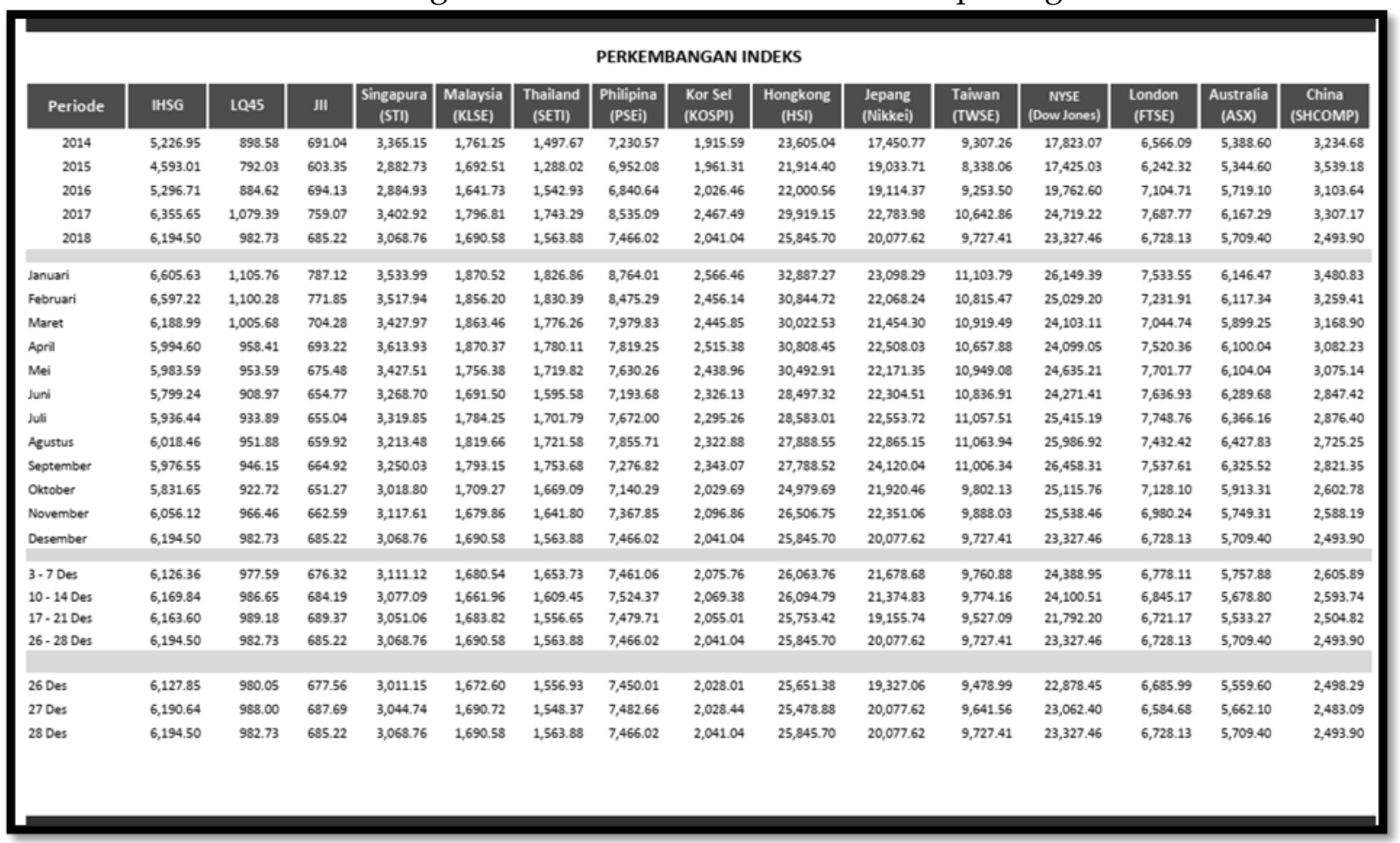

Sumber: Statistik Mingguan Pasar Modal, Minggu ke 4 Desember 2018, www.ojk.go.id

Data pada tabel 1 menunjukkan bahwa ISSI (Indeks Saham Syariah Indonesia) yang merupakan indeks syariah di Indonesia diperjual-belikan dengan volume lembar saham yang paling tinggi. Hal ini memberikan indikasi perputaran modal untuk pasar modal syariah diminati oleh investor. Selanjutnya nilai perdagangan indeks justru paling tinggi ada untuk saham-saham terkategori papan utama (Main Board-MBX) hal ini menunjukkan emiten yang merupakan perusahaan besar digemari oleh investor yang berinvestasi di pasar modal Indonesia.

Secara umum, pembagian indeks di Indonesia dibagi per sektor usaha dimana Bursa Efek Indonesia membaginya menjadi sembilan (9) indeks sektoral yaitu AGRI, BASIC-IND, CONSUMER, FINANCE, INFRASTRUCTURE, MINING, MISC-IND, PROPERTY dan TRADE. Selanjutnya, ada pula indeks yang dibuat oleh media atau perusahaan yang disebut sebagai indeks konstituen, seperti KOMPAS 100, INVESTOR 33, PEFINDO 25, BISNIS-27, SMInfra18, MNC36, INFOBANK 15, SRI KEHATI, Investor 33, IGRADE, IDX 30, ISSI, LQ 45, JII, MBX, dan DBX. Indeks terkategori konstituen dalam hal ini lebih populer dibandingkan indeks lainnya, hal ini dikarenakan screening process yang dilakukan oleh lembaga atau perusahaan yang membuatnya.

Upaya untuk mengantisipasi perubahan harga saham setiap hari di pasar modal dilakukan dengan cara menggunakan analisis harga saham. Berdasarkan data harga saham harian maka investor dapat mengetahui dan memprediksi harga pada masa datang dengan menggunakan analisis teknikal. Beberapa permasalahan yang akan dijawab dalam penelitian ini meliputi penerapan metode moving average dalam melakukan prediksi indeks harga saham, selain itu uji signifikansi akan dilakukan untuk menguji keberartian perbedaan antara prediksi pada berbagai indeks di Bursa Efek Indonesia dengan menggunakan metode moving average. 


\section{TINJAUAN PUSTAKA}

\subsection{Analisis Fundamental}

Analisis fundamental menurut Widoatmodjo (2015) merupakan analisis yang melakukan penilaian atas laporan keuangan. Tujuan dari analisis fundamental yaitu untuk mengetahui sifat-sifat dasar dan karakteristik operasional dari suatu perusahaan. Pada prinsipnya analisis fundamental digunakan untuk mengetahui apakah suatu harga dalam kondisi mahal (overvalued) atau murah (undervalued).

\subsection{Analisis Teknikal}

Pendekatan teknikal untuk keputusan investasi merefleksikan ide bahwa harga bergerak dalam trends yang dicerminkan dengan perubahan perilaku investor dalam menaksirkan ekonomi, moneter, politik, dan psikologi. Analisis teknikal dapat dibagi ke dalam 3 area pokok, yaitu: (1) sentiment, (2) flow-of-funds, dan (3) market structure indicators. Sentimen merupakan expectational indicators yang memonitor emosi para investor. Asumsi indikator ini adalah kelompok investor yang berbeda konsisten dengan aksinya pada major market turning points. Flow-of-funds indicators menganalisis posisi finansial dari berbagai macam kelompok investasi untuk mengetahui potensinya dalam membeli dan menjual saham. Harga dimana transaksi tersebut terjadi harus sama antara pembeli dan penjual. Sehingga jumlah uang yang mengalir ke luar harus sama dengan uang yang mengalir masuk.

Market structure indicators atau character of the market indicators memonitor trend dari berbagai indeks harga, market breadth, siklis, volume dan hal-hal lain dalam rangka mengevaluasi "kesehatan" bull dan bear markets. Biasanya, waktu, harga dan ukuran internal seperti market breadth, momentum, dan volume naik dan turun secara bersama-sama tetapi pada akhir gerakan pasar indikator-indikator ini akan menyimpang dari harganya.

Pergerakan harga dapat diklasifikasikan dalam: (1) gerakan pokok atau primary/cyclical yang merefleksikan sikap investor terhadap siklus bisnis dengan periode 1 sampai 3 tahun; (2) intermediate dengan periode 3 minggu sampai beberapa bulan; dan (3) short term movement dengan periode 3 atau 4 minggu cenderung bersifat random.

\subsection{Teori dalam Analisis Teknikal}

Sukamulja (2020) menungkapkan beberapa teori yang dapat digunakan untuk melakukan analisis teknikal yaitu:

\section{Dow Theory}

Teori ini didasarkan pada arah sebuah trend dan tidak pada nilai prediksi durasi puncak atau ukuran dari trend. Asumsi teori Dow adalah mayoritas saham mengikuti trend pasar yang ada pada waktu itu. Pasar mempunyai tiga buah gerakan, yaitu primary movement, secondary reactions, dan minor movement. Yang terpenting adalah primary/major trend yang biasanya dikenal dengan sebutan bull (rising) atau bear (falling) market:
A. Major Trend/primary trend: 1 tahun sampai 2 tahun atau lebih
B. Intermediate trend: 3 minggu-6 bulan, seperti gelombang (wave)
C. Minor Trend: 1 minggu-3 minggu, seperti riak air (ripples).
Dengan adanya intraday data melalui automatic trading mechanism, maka intraday trend juga dapat diperoleh berdasarkan atas real-time trading.

2. Eliot Wave Principle

Eliot di tahun 1930-an melakukan penelitian yang menunjukkan adanya 5 wave, 3 naik dan 2 turun. Jika harga bergerak naik, kemudian turun, naik lagi tetapi lebih tinggi dan kemudian turun lagi, maka kejadian ini memberikan indikasi harga 


\title{
Jurnal Magister Manajemen UnramVol. 9, No 2. Juni 2020
}

\author{
NATIONALLY ACCREDITED JOURNAL - DECREE NO. 21/E/KPT/2018
}

bersifat Head and Shoulder (HES) sehingga harapannya pola akan berulang lagi diwaktu akan datang. HES merupakan grafik pola yang paling reliabel. Pola $H \mathcal{E S}$ merupakan formasi yang amat cocok untuk melihat indikasi trend yang membalik (trend reversal). Umumnya, volume akan menjadi relatif tinggi pada dasar bahu kiri dan selama pembentukannya pada kepala. Faktor utama yang penting adalah melihat aktivitas bahu kanan yang menurun ke lembah dan melebar secara berarti pada titik patahnya.

Menurut Eliot dalam Sukamulja (2020) semua perubahan pasar saham dapat dibagi ke dalam gelombang-gelombang atau siklus-siklus dari berbagai magnitudes (besaran) dan masing-masing gelombang dapat dibagi lagi ke dalam gelombanggelombang dari magnitude yang lebih kecil. Eliot memberikan terminology untuk menggambarkan magnitude ini dan menyebutnya dalam urutan menurun atas dasar pentingnya, yaitu Grand Super Cycle, Super Cycle, Cycle, Primary, Intermediate, dan Minor.

\section{Breadth Index (BI)}

Breadth Index di dasarkan pada saham-saham yang naik dan turun setiap hari, pada volume saham yang diperdagangkan pada hari-hari naik dan turun. Perhitungan BI dapat diilustrasikan sebagai contoh. Misalnya dalam satu minggu tertentu terdapat 800 saham naik, 400 turun, dan 200 tidak berubah, maka

\section{$B I=[(800-400) / 200]=2$ total minggu sebelumnya}

Pentingnya BI terletak pada confirmation dan non confirmation dari puncak-puncak (peak) penting dalam rata-ratanya. Pada umumnya, jika peaks di confirmed oleh BI berarti market leadership cukup lebar sehingga tidak ada penurunan dalam waktu dekat. Jika BI menolak untuk mengkonfirmasikan new highs in the averages, berarti kenaikan tersebut dibatasi oleh relatif sedikit saham dan suatu penurunan mungkin terjadi. Jika BI gagal melebihi ketinggian pada peak yang baru, maka penampilan yang buruk ini memberikan suatu peringatan dini atas adanya break yang sangat tajam. Up side volume adalah volume pada hari-hari lebih banyak saham yang naik. Down side volume adalah volume pada hari-hari lebih banyak saham yang turun.

\section{METODE PENELITIAN}

\subsection{Jenis Penelitian}

Jenis penelitian ini mengacu pada Sarmanu (2017) yang membagi jenis penelitian berdasarkan tujuannya yaitu mengetahui prediksi dan menguji signifkansi maka penelitian ini dikelompokkan ke dalam kelompok penelitian kuantitatif, yaitu penelitian yang bertujuan menguji teori yang selama ini berlaku apakah benar atau salah.

3.2 Objek Penelitian

Objek dalam penelitian ini adalah indeks saham atau kumpulan saham yang diperjualbelikan di Bursa Efek Indonesia, dimana indeks saham tersebut terbagi menjadi indeks saham sektoral dan indeks saham konstituen

\subsection{Metode Pengumpulan Data}

Pengumpulan data dalam penelitian ini dilakukan dengan metode sampling. Penggunaan aplikasi chartnexus membatasi data yang tersedia sehingga sample yang digunakan untuk penelitian ini terbatas pada sampel yang disediakan oleh chartnexus.

\subsection{Populasi dan Sampel Penelitian}

Populasi dalam penelitian ini adalah saham yang aktif di Bursa Efek Indonesia sampai tahun 2018. Sampelnya adalah saham yang termasuk dalam indeks yang tertera pada aplikasi chartnexus ${ }^{\circledR}$. Data sekunder atas harga sampel saham diperoleh dari harga harian yang dipublikasikan oleh chartnexus ${ }^{\circledR}$. Pengamatan metode simple moving average 


\section{Jurnal Magister Manajemen UnramVol. 9, No 2. Juni 2020}

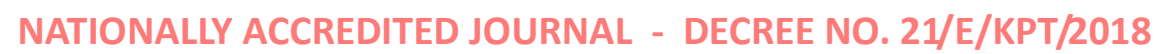

dilakukan dengan menggunakan bantuan aplikasi chartnexus®. Periode yang digunakan dalam penelitian dimulai dari tahun 2016 sampai tahun 2018.

3.5 Definisi Operasional Variabel Penelitian

Variabel dalam penelitian ini adalah harga saham harian, yaitu harga yang dibentuk dari interaksi para penjual dan pembeli saham yang tercatat, terpublikasi dan dapat diakses menggunakan internet maupun tersedia di aplikasi chartnexus.

3.6 Teknik Analisis Data

Teknik analisis data yang digunakan dalam penelitian ini adalah teknik analisis dengan metode Simple Moving Average dengan menggunakan aplikasi chartnexus®.

\section{HASIL PENELITIAN DAN PEMBAHASAN}

\subsection{Hasil Penelitian}

Prediksi merupakan elemen penting dari permintaan saham. Ini memberikan perkiraan kebutuhan masa depan dan dasar untuk perencanaan dan keputusan bisnis yang sehat. Oleh karena itu semua organisasi menghadapi masa depan yang tidak diketahui, dikarenakan beberapa kesalahan antara perkiraan dan permintaan aktual yang diharapkan.

\subsubsection{Tahapan dalam Prediksi dengan menggunakan metode Simple Moving Average}

\section{Menetapkan Periode}

Periode dalam melakukan prediksi adalah hal yang patut di perhitungkan sebelum melakukan peramalan dengan metode Simple Moving Average. Periode prediksi digunakan untuk perhitungan jumlah periode. Di dalam penelitian ini menggunakan periode prediksi dari tahun 2016 sampai dengan 2018. Data harga penutupan ringkasan Indeks dikumpulkan per minggu dari tahun 2016 dan 2018. Di setiap minggu selama tahun 2016 sampai dengan 2018, data dikutip dua (2) kali yaitu di awal pekan dan diakhir pekan sehingga terkumpul 303 data harga penutupan dari 31 indeks yang ada di Bursa Efek Indonesia.

2. Menghitung prediksi nilai penutupan indeks dengan metode Simple Moving Average

Berdasarkan data nilai penutupan indeks pada Bursa Efek Indonesia dapat dihitung data prediksi. Penerapan metode simple moving averages untuk prediksi nilai saham digunakan dengan menjumlahkan nilai penutupan indeks dan membaginya dengan jumlah periode prediksi yang digunakan, yaitu 20, 50, 100 dan 200.

Proses pertama yang dilakukan adalah menyiapkan nilai penutupan indeks yang akan di prediksi. Setelah itu, menentukan jumlah periode yang akan di prediksi. Pada kolom selanjutnya terdapat kolom prediksi yang fungsinya untuk data prediksi nilai penutupan berbagai indeks.

Proses kedua, yaitu penghitungan data prediksi dengan rumus metode simple moving average. Data yang akan di prediksi yaitu data nilai penutupan berbagai indeks selama tahun 2016 sampai dengan 2018. Adapun rumus simple moving averages sebagai berikut: 


$$
F_{t+1}=\frac{\sum_{i=t+1}^{t} A_{i}}{n}
$$

dimana :

$\mathrm{Ft}+1=$ Forecasting atau Prediksi waktu $\mathrm{t}+1$

$\sum_{\mathrm{i}=t+1}^{\mathrm{t}} \mathrm{A}_{\mathrm{i}}=$ adalah jumlah data selama periode waktu tertentu, yaitu 20, 50, 100 dan 200

$\mathrm{N} \quad=$ jumlah periode peramalan

\subsubsection{Hasil Statistik Deskriptif}

Hasil rekapitulasi data penutupan dari berbagai indeks selama periode 2016 sampai dengan 2018 dan hasil prediksi indeks saham dengan menggunakan metode simple moving average 20, 50, 100, dan 200 kemudian diulas dengan menggunakan statistik untuk mendapatkan gambaran nilai rerata, maksimum, minimum dan standar deviasi. Berikut akan disajikan statistik deskriptif dari tiga puluh satu indeks (31) yang ada di Bursa Efek Indonesia tahun 2016 s.d 2018:

Tabel 1. Statistik Deskriptif Nilai Penutupan Berbagai Indeks di Bursa Efek Indonesia

\begin{tabular}{|l|r|r|r|r|r|}
\hline \multicolumn{7}{|c|}{ Descriptive Statistics } \\
\hline & $\mathrm{N}$ & Minimum & Maximum & \multicolumn{1}{c|}{ Mean } & Std. Deviation \\
\hline COMPOSITE & 303 & 4456.74 & $\mathbf{6 6 8 9 . 2 9}$ & 5621.2692 & 522.56591 \\
\hline AGRI & 303 & 1423.40 & 1915.34 & 1715.8342 & 125.24739 \\
\hline MINING & 303 & 775.28 & 2173.55 & 1484.9333 & 361.60690 \\
\hline BASIC_IND & 303 & 387.50 & 854.73 & 615.7209 & 134.99421 \\
\hline MISC_IND & 303 & 786.07 & 1536.73 & 1307.0293 & 113.29617 \\
\hline CONSUMER & 303 & 1053.13 & 2947.39 & 2460.0943 & 179.45751 \\
\hline PROPERTY & 303 & 400.48 & 587.92 & 496.1477 & 40.14710 \\
\hline INFRASTRUCTURE & 303 & 960.83 & 1245.16 & 1094.1021 & 67.45593 \\
\hline FINANCE & 303 & 595.41 & 1214.59 & 926.3814 & 168.14320 \\
\hline TRADE & 303 & 777.36 & 969.04 & 871.7596 & 45.59632 \\
\hline MANUFACTURE & 303 & 1125.33 & 1714.83 & 1445.8362 & 119.85251 \\
\hline LQ45 & 303 & 773.44 & 1128.25 & 934.7386 & 75.48312 \\
\hline JII & 303 & 586.71 & 798.77 & 700.3142 & 44.92913 \\
\hline MBX & 303 & 1273.86 & 1904.13 & 1597.1561 & 141.80340 \\
\hline DBX & 303 & 651.73 & 1069.30 & 871.7939 & 117.94245 \\
\hline KOMPAS100 & 303 & 960.15 & 1421.50 & 1179.8716 & 98.32434 \\
\hline BISNIS27 & 303 & 386.18 & 607.89 & 494.9383 & 53.19630 \\
\hline PEFINDO25 & 303 & 303.32 & 423.57 & 362.8827 & 27.89374 \\
\hline SRIKEHATI & 303 & 259.67 & 410.49 & 336.3333 & 36.45430 \\
\hline ISSI & 303 & 140.41 & 199.61 & 175.6153 & 11.99134 \\
\hline IDX30 & 303 & 404.34 & 616.39 & 506.5619 & 46.40222 \\
\hline INFOBANK15 & 303 & 492.75 & 961.26 & 711.7521 & 136.42666 \\
\hline SMINFRA18 & 303 & 294.94 & 403.22 & 346.3482 & 28.29172 \\
\hline MNC36 & 303 & 252.34 & 385.95 & 319.1782 & 31.18322 \\
\hline INVESTOR33 & 303 & 316.78 & 481.82 & 399.9597 & 39.88254 \\
\hline IGRADE & 105 & 139.95 & 179.42 & 157.0379 & 11.55956 \\
\hline IDXSMC_COM & 105 & 240.73 & 275.51 & 257.8090 & 9.30626 \\
\hline
\end{tabular}




\section{Jurnal Magister Manajemen UnramVol. 9, No 2. Juni 2020}

NATIONALLY ACCREDITED JOURNAL - DECREE NO. 21/E/KPT/2018

\begin{tabular}{|l|r|r|r|r|r|}
\hline IDXSMCLIQ & 105 & 272.26 & 366.17 & 314.2338 & 25.84886 \\
\hline IDXHIDIV20 & 62 & 463.33 & 518.75 & 490.2887 & 16.11197 \\
\hline IDXBUMN20 & 62 & 341.39 & 396.69 & 368.6755 & 15.18568 \\
\hline JII70 & 62 & 208.23 & 229.53 & 218.9465 & 5.26864 \\
\hline Valid N (listwise) & 62 & & & & \\
\hline
\end{tabular}

Sumber: Data Sekunder Diolah

Berdasarkan tabel diatas dapat dilihat bahwa IHSG sebagai indeks yang mengukur pergerakan semua saham yang tercatat di Bursa Efek Indonesia menunjukkan nilai penutupan maksimum sebesar 6689.29 dan nilai minimum ada pada IGRADE, merupakan indeks yang mengukur performa harga dari 30 saham emiten yang memiliki peringkat investment grade dari PEFINDO (idAAA hingga idBBB-) yang berkapitalisasi paling besar. Besaran standar deviasi yang kurang dari besaran mean menunjukkan sebaran data yang baik. Selanjutnya adalah Tabel 2 yang menggambarkan statistik deskriptif untuk prediksi indeks saham berdasarkan moving average 20, 50, 100 dan 200 .

Tabel 2. Statistik Deskriptif Prediksi Moving Average (MA) 20, 50, 100, 200 Berbagai Indeks di Bursa Efek Indonesia

\begin{tabular}{|l|r|r|r|r|r|}
\hline \multicolumn{5}{|c|}{ Descriptive Statistics } & \\
\hline & N & Minimum & Maximum & \multicolumn{1}{c|}{ Mean } & $\begin{array}{c}\text { Std. } \\
\text { Deviation }\end{array}$ \\
\hline MA_COMPOSITE_20 & 283 & 4658.72 & $\mathbf{6 5 4 2 . 7 7}$ & 5639.1896 & 484.62605 \\
\hline MA_COMPOSITE_50 & 253 & 4762.29 & $\mathbf{6 3 2 2 . 8 2}$ & 5674.2683 & 438.08400 \\
\hline MA_COMPOSITE_100 & 203 & 5025.18 & $\mathbf{6 1 1 9 . 9 5}$ & 5710.8090 & 369.78725 \\
\hline MA_COMPOSITE_200 & 103 & 5375.85 & 5919.79 & 5711.1920 & 150.62400 \\
\hline MA_AGRI_20 & 283 & 1481.98 & 1878.79 & 1724.7166 & 114.43826 \\
\hline MA_AGRI_50 & 253 & 1552.28 & 1891.74 & 1767.4075 & 106.27694 \\
\hline MA_AGRI_100 & 203 & 1572.50 & 1831.05 & 1746.3349 & 84.72389 \\
\hline MA_AGRI_200 & 103 & 1679.38 & 1789.27 & 1746.9508 & 34.04830 \\
\hline MA_MINING_20 & 283 & 811.47 & 2013.19 & 1497.8153 & 340.86568 \\
\hline MA_MINING_50 & 253 & 904.77 & 1949.82 & 1509.2918 & 302.57741 \\
\hline MA_MINING_100 & 203 & 1078.47 & 1900.00 & 1511.2646 & 231.38509 \\
\hline MA_MINING_200 & 103 & 1274.75 & 1687.67 & 1510.7098 & 126.05354 \\
\hline MA_BASIC_IND_20 & 283 & 408.82 & 807.03 & 615.3358 & 126.64793 \\
\hline MA_BASIC_IND_50 & 253 & 416.52 & 790.74 & 616.9464 & 115.87509 \\
\hline MA_BASIC_IND_100 & 203 & 461.85 & 774.67 & 616.9389 & 91.01175 \\
\hline MA_BASIC_IND_200 & 103 & 534.26 & 692.24 & 616.8119 & 47.55154 \\
\hline MA_MISC_IND_20 & 283 & 1094.93 & 1487.45 & 1312.1275 & 93.77395 \\
\hline MA_MISC_IND_50 & 253 & 1142.38 & 1441.70 & 1322.8216 & 76.56442 \\
\hline MA_MISC_IND_100 & 203 & 1234.47 & 1406.71 & 1342.9540 & 49.89770 \\
\hline MA_MISC_IND_200 & 103 & 1316.18 & 1357.07 & 1343.7557 & 9.25535 \\
\hline MA_CONSUMER_20 & 283 & 2167.33 & 2874.92 & 2472.2457 & 142.20214 \\
\hline MA_CONSUMER_50 & 253 & 2256.83 & 2737.17 & 2485.7001 & 117.98838 \\
\hline MA_CONSUMER_100 & 203 & 2341.01 & 2619.32 & 2499.4869 & 90.72264 \\
\hline MA_CONSUMER_200 & 103 & 2412.59 & 2520.50 & 2499.3424 & 26.63102 \\
\hline MA_PROPERTY_20 & 283 & 435.55 & 597.59 & 523.8214 & 39.13812 \\
\hline MA_PROPERTY_50 & 253 & 431.95 & 553.52 & 504.0215 & 29.83705 \\
\hline MA_PROPERTY_100 & 203 & 465.40 & 531.71 & 506.5505 & 18.44309 \\
\hline
\end{tabular}


Jurnal Magister Manajemen UnramVol. 9, No 2. Juni 2020

NATIONALLY ACCREDITED JOURNAL - DECREE NO. 21/E/KPT/2018

\begin{tabular}{|c|c|c|c|c|c|}
\hline MA_PROPERTY_200 & 104 & 483.01 & 517.62 & 506.2527 & 11.50323 \\
\hline MA_INFRASTRUCTURE_20 & 283 & 993.96 & 1223.72 & 1099.1516 & 60.25074 \\
\hline MA_INFRASTRUCTURE_50 & 253 & 1031.13 & 1188.34 & 1107.1266 & 48.73477 \\
\hline MA_INFRASTRUCTURE_100 & 203 & 1067.47 & 1167.08 & 1115.8193 & 30.82395 \\
\hline MA_INFRASTRUCTURE_200 & 103 & 1104.93 & 1126.68 & 1116.2248 & 7.30080 \\
\hline MA_FINANCE_20 & 283 & 670.63 & 1179.86 & 926.3404 & 159.72867 \\
\hline MA_FINANCE_50 & 253 & 680.72 & 1134.70 & 931.4705 & 149.00465 \\
\hline MA_FINANCE_100 & 203 & 730.68 & 1103.07 & 938.7565 & 128.00082 \\
\hline MA_FINANCE_200 & 103 & 834.68 & 1024.14 & 938.8031 & 53.51100 \\
\hline MA_TRADE_20 & 283 & 790.44 & 945.05 & 876.9662 & 39.85607 \\
\hline MA_TRADE_50 & 253 & 820.59 & 926.71 & 883.6064 & 31.89023 \\
\hline MA_TRADE_100 & 203 & 842.37 & 920.37 & 888.9461 & 23.86863 \\
\hline MA_TRADE_200 & 103 & 871.80 & 895.67 & 889.1338 & 6.46959 \\
\hline MA_MANUFACTURE_20 & 283 & 1217.76 & 1667.05 & 1450.1571 & 105.72072 \\
\hline MA_MANUFACTURE_50 & 253 & 1250.77 & 1603.85 & 1457.5292 & 92.72311 \\
\hline MA_MANUFACTURE_100 & 203 & 1316.47 & 1552.61 & 1466.1808 & 76.57651 \\
\hline MA_MANUFACTURE_200 & 103 & 1391.06 & 1510.46 & 1466.2132 & 31.84548 \\
\hline MA_LQ45_20 & 283 & 812.44 & 1101.17 & 938.0517 & 69.65096 \\
\hline MA_LQ45_50 & 253 & 841.39 & 1076.04 & 963.8262 & 62.11963 \\
\hline MA_LQ45_100 & 203 & 863.21 & 1013.86 & 952.3041 & 50.12436 \\
\hline MA_LQ45_2 & 103 & 909.15 & 970.77 & 952.3730 & 16.44309 \\
\hline MA_JII_20 & 283 & 620.69 & 773.53 & 704.4475 & 38.98431 \\
\hline MA_JII_50 & 253 & 643.14 & 750.70 & 710.9631 & 29.45101 \\
\hline MA_JII_100 & 203 & 682.01 & 743.96 & 717.6682 & 16.58042 \\
\hline MA_JII_200 & 103 & 704.55 & 726.24 & 717.8148 & 6.35303 \\
\hline MA_MBX_ & 283 & 1337.59 & 1860.87 & 1602.4785 & 130.80511 \\
\hline MA_MBX_50 & 253 & 1368.13 & 1795.53 & 1612.3340 & 117.77234 \\
\hline MA_MBX_ & 203 & 1440.53 & 1733.06 & 1622.2241 & 99.78662 \\
\hline MA_MBX_200 & 103 & 1532.35 & 1675.73 & 1622.2966 & 39.22600 \\
\hline MA_DBX_20 & 283 & 661.33 & 1007.32 & 873.5294 & 111.44703 \\
\hline MA_DBX_50 & 253 & 673.19 & 990.06 & 879.3336 & 101.21221 \\
\hline MA_DBX_1 & 203 & 723.79 & 987.22 & 887.0081 & 81.22572 \\
\hline MA_DBX_200 & 103 & 811.99 & 945.31 & 887.2236 & 39.41177 \\
\hline MA_KOMPAS100_20 & 283 & 1007.77 & 1384.88 & 1184.1251 & 90.34883 \\
\hline MA_KOM & 253 & 1026.90 & 1329.91 & 1192.1791 & 80.19196 \\
\hline MA_KOMPAS100_100 & 203 & 1078.70 & 1276.37 & 1200.6378 & 66.69124 \\
\hline MA_KOMPAS100_200 & 103 & 1140.36 & 1230.72 & 1200.6910 & 24.56919 \\
\hline MA_BISNIS27_20 & 283 & 402.83 & 592.57 & \begin{tabular}{|l}
496.3367 \\
\end{tabular} & 49.30918 \\
\hline MA_BISNIS27_50 & 253 & 409.05 & 568.62 & 499.9280 & 44.16635 \\
\hline MA_BISNIS27_100 & 203 & 436.38 & 545.05 & 504.3578 & 37.23482 \\
\hline MA_BISNIS27_200 & 103 & 471.78 & 524.24 & 504.4156 & 14.19220 \\
\hline MA_PEFINDO_20 & 283 & 311.47 & 413.39 & 365.5975 & 25.12177 \\
\hline MA_PEFINDO_50 & 253 & 324.57 & 402.67 & 368.5682 & 20.51472 \\
\hline MA_PEFINDO_100 & 203 & 340.22 & 391.16 & 369.0055 & 15.98695 \\
\hline MA_PEFINDO_200 & 103 & 354.17 & 376.21 & 368.9981 & 7.40235 \\
\hline MA_SRIKEHATI_20 & 283 & 274.20 & 399.92 & 337.1951 & 33.70581 \\
\hline MA_SRIKEHATI_50 & 253 & 278.82 & 386.17 & 339.5555 & 30.51062 \\
\hline MA_SRIKEHATI_100 & 203 & 295.78 & 371.52 & 342.6751 & 25.95490 \\
\hline
\end{tabular}


Jurnal Magister Manajemen UnramVol. 9, No 2. Juni 2020

NATIONALLY ACCREDITED JOURNAL - DECREE NO. 21/E/KPT/2018

\begin{tabular}{|c|c|c|c|c|c|}
\hline MA_SRIKEHATI_200 & 103 & 320.87 & 356.66 & 342.7352 & 9.55319 \\
\hline MA_ISSI_20 & 283 & 146.96 & 194.43 & 176.5029 & 10.31444 \\
\hline MA_ISSI_50 & 253 & 153.31 & 188.92 & 177.9167 & 8.24616 \\
\hline MA_ISSI_100 & 203 & 163.82 & 186.57 & 179.3624 & 6.16153 \\
\hline MA_ISSI_200 & 103 & 172.66 & 181.51 & 179.3961 & 2.46541 \\
\hline MA_IDX30_20 & 283 & 425.64 & 602.63 & 508.5290 & 42.67573 \\
\hline MA_IDX30_50 & 253 & 434.21 & 577.88 & 512.5451 & 37.40531 \\
\hline MA_IDX30_100 & 203 & 460.17 & 553.99 & 517.3231 & 30.60975 \\
\hline MA_IDX30_200 & 103 & 490.27 & 529.89 & 517.3843 & 10.52933 \\
\hline MA_INFOBANK15_20 & 283 & 507.45 & 927.91 & 711.3079 & 130.11573 \\
\hline MA_INFOBANK15_50 & 253 & 521.17 & 889.67 & 715.3035 & 122.32082 \\
\hline MA_INFOBANK15_100 & 203 & 554.96 & 854.42 & 721.3233 & 105.80047 \\
\hline MA_INFOBANK15_200 & 103 & 637.56 & 790.13 & 721.3479 & 42.91125 \\
\hline MA_SMINFRA18_20 & 283 & 304.45 & 390.40 & 348.6972 & 25.86531 \\
\hline MA_SMINFRA18_50 & 253 & 308.37 & 382.33 & 352.4855 & 21.21285 \\
\hline MA_SMINFRA18_100 & 203 & 332.01 & 377.56 & 357.2454 & 12.95358 \\
\hline MA_SMINFRA18_200 & 103 & 350.35 & 362.40 & 357.4075 & 3.90131 \\
\hline MA_MNC36_20 & 283 & 263.89 & 375.33 & 320.0977 & 28.76582 \\
\hline MA_MNC36_50 & 253 & 269.02 & 361.59 & 322.1843 & 25.87839 \\
\hline MA_MNC36_100 & 203 & 283.98 & 348.16 & 324.7252 & 21.92498 \\
\hline MA_MNC36_200 & 103 & 305.52 & 336.81 & 324.7689 & 8.46661 \\
\hline MA_INVESTOR33_20 & 283 & 332.82 & 469.79 & 400.7970 & 36.65867 \\
\hline MA_INVESTOR33_50 & 253 & 338.16 & 454.66 & 403.3168 & 33.11960 \\
\hline MA_INVESTOR33_100 & 203 & 356.67 & 438.53 & 406.6043 & 28.28515 \\
\hline MA_INVESTOR33_200 & 103 & 383.19 & 421.66 & 406.6632 & 10.14593 \\
\hline MA_IGRADE_20 & 84 & 153.12 & 182.97 & 162.9987 & 10.79045 \\
\hline MA_IGRADE_50 & 54 & 149.91 & 168.08 & 156.4319 & 5.87075 \\
\hline MA_IGRADE_100 & 4 & 158.21 & 158.51 & 158.3719 & .12712 \\
\hline MA_IDXSMC_20 & 84 & 258.02 & 283.85 & 271.8173 & 7.92479 \\
\hline MA_IDXSMC_50 & 54 & 256.73 & 269.65 & 264.2136 & 4.52294 \\
\hline MA_IDXSMC_100 & 3 & 260.65 & 260.69 & 260.6705 & .02008 \\
\hline MA_IDXSMCLIQ_20 & 84 & 298.39 & 370.49 & 330.0675 & 24.15058 \\
\hline MA_IDXSMCLIQ_50 & 54 & 299.47 & 342.36 & 319.2109 & 14.40202 \\
\hline MA_IDXSMCLIQ_100 & 4 & 317.20 & 318.15 & 317.6919 & .40839 \\
\hline MA_IDXHIDIV_20 & 41 & 505.69 & 526.80 & 511.3871 & 5.26646 \\
\hline MA_IDXHIDIV_50 & 11 & 495.30 & 501.00 & 497.8609 & 1.75061 \\
\hline MA_IDXBUMN_20 & 41 & 375.01 & 393.54 & 382.4312 & 4.64566 \\
\hline MA_IDXBUMN_50 & 11 & 371.48 & 374.85 & 372.8417 & 1.02030 \\
\hline MA_JII70_20 & 41 & 225.10 & 232.09 & 228.2077 & 1.98677 \\
\hline MA_JII70_50 & 11 & 371.48 & 374.85 & 372.8417 & 1.02030 \\
\hline Valid N (listwise) & 3 & & & & \\
\hline
\end{tabular}

Sumber: Data Sekunder Diolah

Serupa dengan tabel data historis dari berbagai indeks di Bursa Efek Indonesia, sebaran data prediksi moving average 20, 50, 100, dan 200 nampak baik nampak terlihat dari nilai standar deviasi yang kurang dari nilai mean-nya. Untuk nilai prediksi berbagai indeks saham dengan metode Moving Average (MA) 20, 50, 100, dan 200, nampak superioritas IHSG sebagai indeks populasi di Bursa Efek Indonesia, dengan nilai 
maksimum yang 6542.77; 6322.82; 6119.95 dan 5919.79 sementara nilai minimum untuk prediksi nilai MA pada berbagai indeks adalah ISSI MA 20, dengan besaran 146.96; IGRADE MA 50, dengan besaran 149.91; IGRADE MA 100, 158.21, dan ISSI MA 200, dengan besaran 172.66 .

\subsubsection{Perbandingan antara Analisis Teknikal dengan Penerapan Metode Moving Average Manual, dengan Microsoft Excel, dan Aplikasi @ChartNexus}

Chartnexus merupakan sebuah aplikasi dengan tujuan mengelola grafis terutama untuk analisa pergerakan harga saham dan index yang bersifat gratis. Tidak semua indeks yang ada di Bursa Efek Indonesia terangkum dalam (CChartNexus, indeks yang ada di (C) ChartNexus terbatas pada: 1)AGRI; 2)BASIC-IND; 3)BISNIS-27; 4)COMPOSITE; 5)CONSUMER; 6)DBX; 7)FINANCE; 8)INFRASTRUCTURE; 8)JII; 9)KOMPAS100; 10)LQ45; 11)MANUFACTURE; 12)MBX; 13)MINING; 14)MISC-IND; 15)PROPERTY; 16)TRADE. Berikut salah satu perbandingan antara output dari ChartNexus dan Grafik dari Microsoft Excel. Pola yang ditunjukkan serupa antara luaran dari microsoft excel dan ChartNexus ${ }^{\circledR}$ :

\section{Gambar 1. Output AGRI}

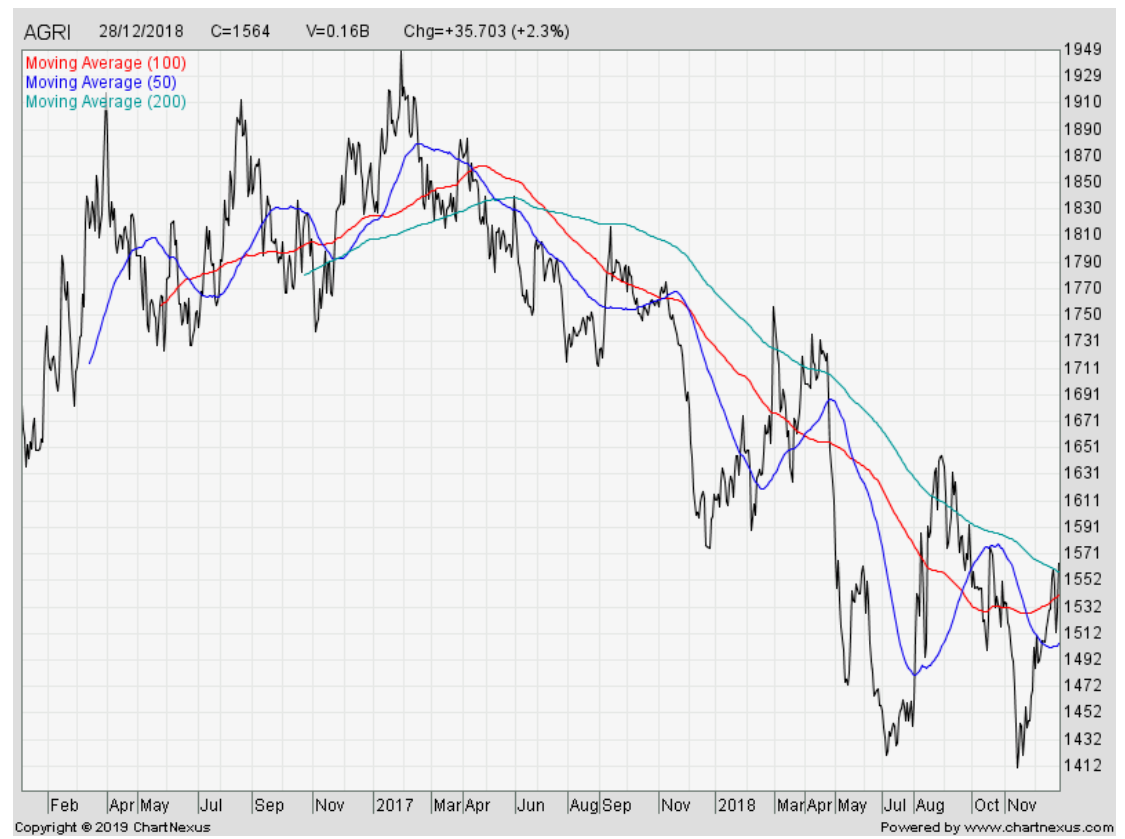

Grafik 1. Grafik MA AgrI 


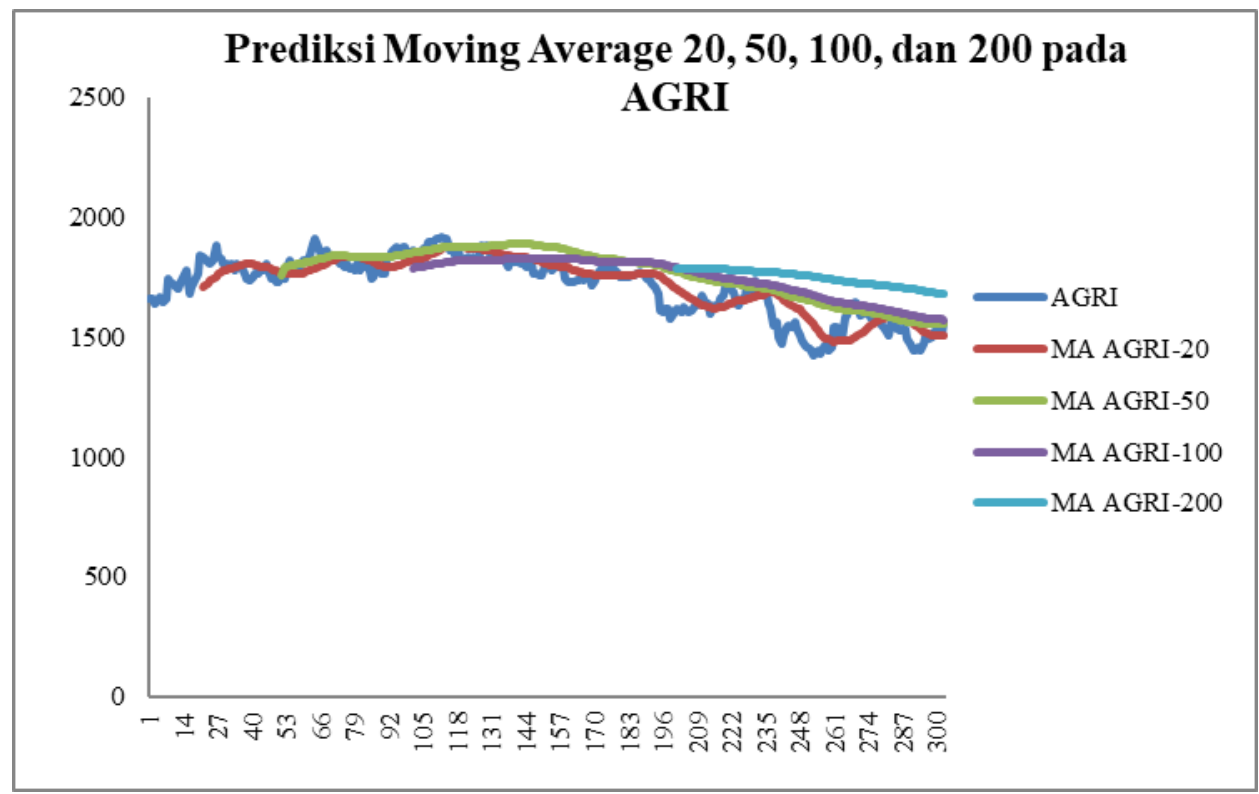

4.1.4 Uji Normalitas untuk Kelompok Moving Average pada Berbagai Indeks

Berikut disajikan uji normalitas untuk masing-masing kelompok prediksi moving average.

Tabel Uji Normalitas Prediksi Moving Average 20

\begin{tabular}{|c|c|c|c|}
\hline \multicolumn{4}{|c|}{ Tests of Normality } \\
\hline & Statistic & df & Sig. \\
\hline MA_20 & .201 & 7450 & .000 \\
\hline
\end{tabular}

Tabel Uji Normalitas Prediksi Moving Average 50

\begin{tabular}{lr|c|c} 
& \multicolumn{3}{c}{ Tests of Normality } \\
& \multicolumn{2}{c}{ Kolmogorov-Smirnova } \\
& Statistic & df & Sig. \\
\hline MA_50 & .198 & 6520 & .000 \\
\hline
\end{tabular}

a. Lilliefors Significance Correction

Tabel Uji Normalitas Prediksi Moving Average 100

Tests of Normality

Kolmogorov-Smirnova

\begin{tabular}{lr|r|r} 
& Statistic & df & \multicolumn{1}{c}{ Sig. } \\
\hline MA_100 & .196 & 5085 & .000 \\
\hline
\end{tabular}

a. Lilliefors Significance Correction 
Tabel Uji Normalitas Prediksi Moving Average 200

\begin{tabular}{|c|c|c|c|c|c|c|}
\hline \multicolumn{7}{|c|}{ Tests of Normality } \\
\hline & \multicolumn{3}{|c|}{ Kolmogorov-Smirnova } & \multicolumn{3}{|c|}{ Shapiro-Wilk } \\
\hline & Statistic & $\mathrm{df}$ & Sig. & Statistic & $\mathrm{df}$ & Sig. \\
\hline MA_200 & .198 & 2575 & .000 & .639 & 2575 & .000 \\
\hline
\end{tabular}

a. Lilliefors Significance Correction

Dari serangkaian uji normalitas diatas menunjukkan bahwa kelompok indeks tersebut tidak terdistribusi normal sehingga untuk pengujian beda, selanjutnya akan dilakukan dengan statistik non parametrik yaitu tes Kruskal Wallis $\mathrm{H}$

\subsubsection{Uji Signifikansi Beda MA Pada Berbagai Indeks}

Tabel Uji Kruskal-Wallis H pada MA 20

Test Statistics ${ }^{a, b}$

\begin{tabular}{lc} 
& MA_20 \\
\hline $\begin{array}{c}\text { Kruskal-Wallis } \\
\text { H }\end{array}$ & 7240.234 \\
\hline df & 30 \\
\hline Asymp. Sig. & .000 \\
\hline a. Kruskal Wallis Test \\
b. Grouping Variable: \\
INDEKS
\end{tabular}

Tabel Kruskal Wallis H pada MA 50 Berbagai Indeks Test Statistics $a, b$

\begin{tabular}{lr} 
& \multicolumn{1}{c}{ MA_50 } \\
\hline Kruskal-Wallis & 6364.477 \\
$\mathrm{H}$ & \\
\hline $\mathrm{df}$ & 30 \\
\hline Asymp. Sig. & .000 \\
\hline
\end{tabular}

a. Kruskal Wallis Test

b. Grouping Variable:

INDEKS

Tabel Kruskal-Wallis H pada MA 100 berbagai Indeks

Test Statistics $\mathrm{a}, \mathrm{b}$

\begin{tabular}{lr} 
& MA_100 \\
\hline Kruskal-Wallis & 4994.777 \\
$\mathrm{H}$ & \\
\hline df & 27 \\
\hline Asymp. Sig. & .000 \\
\hline
\end{tabular}

a. Kruskal Wallis Test

b. Grouping Variable:

INDEKS 
Tabel Kruskal-Wallis $\mathbf{H}$ pada Berbagai Indeks

\begin{tabular}{lr}
\multicolumn{2}{|c}{ Test Statistics } \\
& MA_b \\
& MA00 \\
\hline Kruskal-Wallis & 2556.486 \\
H & \\
\hline df & 24 \\
\hline Asymp. Sig. & .000 \\
\hline a. Kruskal Wallis Test \\
b. Grouping Variable: \\
INDEKS
\end{tabular}

\subsection{Pembahasan}

Melihat perbandingan yang ditunjukkan oleh gambar yang merupakan output dari aplikasi ChartNexus ${ }^{\circledR}$ dengan pola yang ditunjukkan oleh grafik luaran Microsoft Excel menunjukkan luaran yang serupa. Dengan mempelajari pola Head and Shoulder yang dikemukakan oleh Eliot, maka para investor dapat mempelajari sinyal jual dan beli dari serangkaian informasi perdagangan. Uji statistik yang menunjukkan signifikansi beda berdasarkan pemeringkatan mean dapat membantu investor untuk memetakan preferensi mereka dalam melakukan investasi. Indeks yang menjadi peringkat atas adalah indeks sektoral bukan indeks konstituen. Hal ini dapat dijadikan dasar dalam melakukan investasi. Sementara indeks konstituen menunjukkan peringkat mean yang lebih rendah.

\section{KESIMPULAN DAN SARAN}

\subsection{Kesimpulan}

1. Analisis Teknikal dengan memprediksi indeks harga saham baik menggunakan aplikasi chartnexus ${ }^{\circledR}$ maupun microsoft excel pada berbagai indeks di Bursa Efek Indonesia menunjukkan sinyal jual dan beli sesuai dengan yang dijelaskan oleh teori eliot wave principle.

2. Terdapat perbedaan yang signifikan pada masing-masing kelompok indeks.

\subsection{Saran}

1. Untuk investor yang ingin berinvestasi disarankan untuk membentuk portofolio pada indeks sektoral yang menunjukkan peringkat mean lebih besar, hal ini sebagai indikasi kemungkinan memperoleh keuntungan lebih.

2. Investor harus jeli melihat sinyal beli serta menyesuaikan kondisi sesuai dengan yang telah ditunjukkan dalam teori Eliot Wave Principle. Hal ini disebabkan perbandingan gambar data prediksi dan historis menunjukkan pola serupa

3. Pemeringkatan Kruskal Wallis $\mathrm{H}$ dapat dijadikan referensi untuk sinyal beli maupun jual pada indeks tertentu

\section{DAFTAR PUSTAKA}

Gumilang, H. (2012). Amibroker Sebuah Pengantar dan Charting Tools. Bogor: HGU Publishing.

Husnan, S. (2001). Dasar-dasar Teori Portofolio dan Analisis Sekuritas. Yogyakarta: UPP AMP YKPN.

Kusumawardana, V. (2016). Komparasi Strategi Investasi Aktif dan Pasif untuk Optimalkan Return Saham yang Terdaftar di Bursa Efek Indonesia. Ekonomika-Bisnis, 41-54. 
Jurnal Magister Manajemen UnramVol. 9, No 2. Juni 2020

NATIONALLY ACCREDITED JOURNAL - DECREE NO. 21/E/KPT/2018

Sarmanu. (2017). Dasar Metodologi Penelitian Kuantitatif Kualitatif dan Statistika. Surabaya: Airlangga University Press.

Sukamulja, S. (2020, April Tuesday). Academia.edu. Retrieved from https://www.academia.edu/:

https://www.academia.edu/39670060/ANALISIS_FUNDAMENTAL_TEKNIKAL_D AN_PROGRAM_METASTOCK_OLEH_PROF._DR._SUKMAWATI_SUKAMULJA

Widoatmodjo, S. (2015). Pengetahuan Pasar Modal untuk Konteks Indonesia. Jakarta: Elex Media Komputindo. 